\title{
EFFECT OF INTERMITTENT HYPOXIC TRAINING ON ORTHOSTATIC TOLERANCE IN HUMANS BEFORE AND AFTER SIMULATED MICROGRAVITY
}

Katuntsev VP $\bowtie$, Sukhostavtseva TV, Kotov AN, Baranov MV

A.I. Burnazyan Federal Medical Biophysical Center of FMBA, Moscow, Russia

Reduced orthostatic tolerance (OT) is a serious concern facing space medicine. This work sought to evaluate the effects of intermittent hypoxic training (IHT) on OT in humans before and after 3 days of head-down bed rest (HDBR) used to model microgravity. The study was carried out in 16 male volunteers aged 18 to 40 years and included 2 series of experiments with 11-day and 21-day IHT administered on a daily basis. During the first IHT session, the concentration of oxygen in the inspired gas mixture was 10\%; for other sessions it was adjusted to 9\%. OT was assessed by a 20-minute-long orthostatic tilt test (OTT) conducted before and after HDBR. Before HDBR, orthostatic intolerance was observed in 3 participants, while after HDBR, it was observed in 9 of 16 volunteers ( $p<0.05)$. During OTT conducted after HDBR, the heart rate $(\mathrm{HR})$ exceeded control values by $26.8 \%(p<0.01)$. Preexposure to any of the applied IHT regimens led to a reduction in the number of volunteers with orthostatic intolerance. After the 11-day IHT program, there was a less pronounced increase in HR during OTT before HDBR; with the extended IHT regimen, less pronounced changes were observed for HR, systolic, diastolic and mean blood pressure (BP). The increase in HR during OTT after HDBR was significantly lower in the group that had completed the 11-day IHT program, while BP remained stable. The changes in HR and systolic BP were less pronounced in the group that had completed the 21-day IHT program than in the control group $(p<0.05)$. Thus, IHT reduced the risk of orthostatic disorders and mitigated changes in cardiovascular parameters during the orthostatic test.

Keywords: intermittent hypoxic training, orthostatic tolerance, head-down bed rest, blood pressure, heart rate

Acknowledgement: the authors thank all volunteers who participated in this study.

Author contribution: Katuntsev VP conceived and designed the study, wrote the manuscript; Sukhostavtseva TV collected and analyzed the obtained data, performed statistical analysis and edited the manuscript; Kotov AN collected and analyzed the obtained data and performed statistical analysis; Baranov MV collected and analyzed the obtained data and edited the manuscript.

Compliance with ethical standards: the study was approved by the Ethics Committee of Federal Research Clinical Center of FMBA (Protocol № 1 dated February $7,2019)$ and conformed with the principles of biomedical ethics laid out in the Declaration of Helsinki (the 1964 version and subsequent updates); voluntary informed consent was obtained from each study participant.

$\triangle$ Correspondence should be addressed: Vladimir P. Katuntsev Dyshinskaya,14, kv. 82, Moscow, 111024; vpkat@yandex.ru

Received: 07.10.2020 Accepted: 23.11.2020 Published online: 13.12.2020

DOI: $10.47183 /$ mes.2020.022

\section{ВЛИЯНИЕ ГИПОКСИЧЕСКИХ ТРЕНИРОВОК НА ОРТОСТАТИЧЕСКУЮ УСТОЙЧИВОСТЬ ЧЕЛОВЕКА ДО И ПОСЛЕ МОДЕЛИРОВАННОЙ МИКРОГРАВИТАЦИИ}

В. П. Катунцев ${ }^{凶}$, Т. В. Сухоставцева, А. Н. Котов, М. В. Баранов

Федеральный медицинский биофизический центр имени А. И. Бурназяна Федерального медико-биологического агентства, Москва, Россия

Снижение ортостатической устойчивости (ОУ) является актуальной проблемой космической медицины. Целью работы было оценить влияние интервальных гипоксических тренировок (ИГТ) на ОУ человека до и после воздействия трехсуточной антиортостатической гипокинезии (АНОГ) как модели микрогравитации. При участии 16 мужчин-добровольцев в возрасте 18-40 лет проведены две серии исследований с 11- и 21-суточным курсом ежедневных ИГТ. В первой ИГТ концентрация кислорода во вдыхаемой газовой смеси составляла 10\%, во всех последующих - $9 \%$. Оценку ОУ выполняли до и после АНОГ проведением 20-минутной ортопробы (ОП). Развитие ортостатической неустойчивости до АНОГ наблюдали у трех, а после АНОГ у девяти из 16 обследуемых ( $<$ 0,05). Во время ОП после АНОГ среднее значение частоты сердечных сокращений (ЧСС) превышало контрольные значения на 26,8\% (p < 0,01). После 11 - и 21-суточных ИГТ отмечена тенденция к снижению числа случаев с развитием ортостатической неустойчивости. По сравнению с контролем при ОП до АНОГ после 11-суточного курса ИГТ наблюдали менее выраженный прирост ЧСС, а при увеличении курса ИГ до 21 суток - менее выраженные реакции со стороны ЧСС, систолического, диастолического и среднего артериального давления (АД). При ОП после АНОГ в серии с 11-суточным курсом ИГТ имело место достоверно меньшее увеличение чСС при стабильном уровне АД. В серии с 21-суточным курсом ИГТ наблюдали меньшие сдвиги ЧСС и систолического АД ( $<$ < 0,05). Таким образом, проведение ИГТ приводило к уменьшению риска ортостатических нарушений и менее выраженным сдвигам показателей сердечно-сосудистой системы во время постуральных воздействий.

Ключевые слова: интервальные гипоксические тренировки, ортостатическая устойчивость, антиортостатическая гипокинезия, артериальное давление, частота сердечных сокращений

Благодарности: авторы выражают благодарность всем добровольцам, принимавшим участие в настоящем исследовании в качестве обследуемых лиц.

Вклад авторов: В. П. Катунцев - концепция и дизайн исследования, написание текста; Т. В. Сухоставцева - сбор и обработка материала, статистическая обработка, редактирование; А. Н. Котов - сбор и обработка материала статистическая обработка; М. В. Баранов - сбор и обработка материала, редактирование.

Соблюдение этических стандартов: исследование одобрено этическим комитетом ФНКЦ ФМБА России (Протокол № 1 от 7 февраля 2019 г.), проведено в соответствии с принципами биомедицинской этики, сформулированными в Хельсинкской декларации 1964 г. и ее последующих обновлениях. Все участники исследования подписали добровольное информированное согласие.

$\bowtie$ Для корреспонденции: Владимир Петрович Катунцев

ул. Душинская, д. 14, кв. 82, г. Москва, 111024; vpkat@yandex.ru

Статья получена: 07.10.2020 Статья принята к печати: 23.11.2020 Опубликована онлайн: 13.12.2020

DOI: $10.47183 /$ mes.2020.022 
Exposure to a natural or modelled microgravity environment leads to the deconditioning of the physiological systems involved in maintaining the upright posture under Earth's gravity. Diminished orthostatic tolerance (OT) is a serious symptom of deconditioning that was recognized in the early days of manned space missions [1, 2]. After short-duration Space Shuttle flights, about 20\% of astronauts were unable to complete a 10-minute orthostatic tilt test (OTT) due to a progressive blood pressure fall and presyncope [3]. Even more American astronauts developed orthostatic intolerance after long-duration missions aboard Mir [3] and the International Space Station (ISS). Besides, ISS astronauts took longer to recover than Space Shuttle crews [4].

Countermeasures against the adverse effects of microgravity on the human body during orbital flights are complex, timeconsuming and include daily exercise for about 2.5 hours [5]. However, they cannot completely avert the development of orthostatic intolerance in the early postflight period $[4,6]$. The first Russian experimental studies investigating the effects of the modeled lunar gravity field on human physiology [7] underscore the significance of this yet unsolved problem for future space missions [8].

Manned space missions to the Moon and beyond to Mars will require more effective and less time-consuming countermeasures enhanced by cutting-edge technologies against the deconditioning effects of micro- and hypogravity on gravity-dependent body systems. Creating artificial gravity on board of a spacecraft is the most radical solution to counter microgravity [9]; in turn, methods for targeted physiological action [10], including adaptation to hypoxic hypoxia [11], might reinforce the effect.

Today, adaptation to hypoxic hypoxia through normobaric or hypobaric intermittent hypoxic training $(\mathrm{IHT})$ is widely used in clinical, sports, aviation and space medicine as a nondrug therapy for restoring body function, improving physical performance and resisting occupational stress [12, 13]. According to some publications, $I \mathrm{HT}$ can reduce the intensity of hemodynamic changes during orthostatic tests [14, 15]. It is reported that a 14-day-long exposure to a hypoxic environment reduces orthostatic hypotension and increases orthostatic tolerance in rats kept in the antiorthostatic position (modeled microgravity) for 2 weeks [16]. The findings of the cited study inspired us to carry out an experiment on human subjects in the attempt to investigate the effects of IHT on OT before and after a 3-day exposure to modeled microgravity.

\section{METHODS}

The study was carried out in 16 healthy, non-smoking male subjects aged 18 to 40 years (the mean age was $26.4 \pm 1.5$ years; the mean body weight, $76.8 \pm 2.6 \mathrm{~kg}$; height, $177 \pm$ $1.9 \mathrm{~cm}$ ) and not involved in professional sports. The following inclusion criteria were applied: approval by the medical board and informed consent to participate. Two days before the experiment, the subjects were accommodated in an inpatient unit for adaptation. During the adaptation period, their condition was closely monitored by the medical personnel. Physical

Table. Effects of 3-day HDBR on orthostatic tolerance in subjects loads were banned. Meals were provided 4 times a day. Sleep time was from 23:00 to 8:00. Microgravity was simulated by 3 days of $-6^{\circ}$ head-down tilt bed rest (HDBR) [17].

IHT sessions were conducted using a Bio-Nova-204 system for hypoxic therapy (Bio-Nova; Russia). The hypoxic gas mixture was delivered to the seated participants through a mask pressed tightly against the face, in a well-ventilated room for physiological tests involving humans. $I \mathrm{HT}$ sessions were held daily and lasted 60 min each. Each session consisted of 6 cycles: 5-minute periods of breathing the hypoxic gas mixture followed by 5 minutes of breathing ambient air. During the first $\mathrm{IHT}$ session, the concentration of oxygen in the inspired gas mixture $\left(\mathrm{FIO}_{2}\right)$ was $10 \%$. Starting from the $2^{\text {nd }}$ session, $\mathrm{FIO}_{2}$ was adjusted to $9 \%$. During $\mathrm{IHT}$, the condition of the participants was closely monitored; oxygen saturation $\left(\mathrm{SpO}_{2}\right)$, heart rate $(\mathrm{HR})$, systolic and diastolic pressures (BP) were taken every 3 minutes.

OT was assessed a day before HDBR and immediately after 3 days of HDBR on a tilt table by transferring the subjects to a vertical position at an angle of $+70^{\circ}$ for the maximum of 20 min. Before, during (every 2 minutes) and after the end of $\mathrm{OTT}$, HR, systolic and diastolic BP were measured. Subjective and objective indicators of health status were evaluated. Prior to OTT, baseline physiological parameters were recorded in the supine position (before hypokinesia) and in the HDBR position (after hypokinesia).

Physiological parameters were measured using a PVM2703 bedside monitor (Nihon Kohden Corporation; Japan) fitted with a pulse oximeter and channels for measuring BP and ECG. Mean BP was computed as the sum of diastolic BP and $1 / 3$ of pulse pressure. OTT was terminated if the tested participant had a progressive BP decrease, bradycardia, nausea, excessive sweating, blurred vision and other signs of imminent syncope. Two different IHT regimens were used. In the first part of the experiment, $\mathrm{IHT}$ duration was 11 days; in the second part, IHT was extended to 21 days. The number of the participants involved was 6 and 11, respectively.

Statistical analysis was carried out in Microsoft Excel ver. 2016 (16.0.5071.1000; Microsoft Corporation; USA). Significance of differences was assessed using the nonparametric Wilcoxon signed-rank test, the Mann-Whitney $U$ test and Fisher's - criterion. Differences were considered significant at $p<0.05$. The table and figures below show the mean values of the studied parameters and the mean error $(\mathrm{M} \pm \mathrm{m})$.

\section{RESULTS}

\section{IHT tolerance by subjects}

During hypoxic gas breathing, the subjects did not feel any discomfort or had any health complaints. $\mathrm{SpO}_{2}$ was falling from $97.0 \pm 0.5 \%$ to $77.6 \pm 2.6 \%$; HR was increasing from $71.7 \pm$ $4.0 \mathrm{~min}^{-1}$ to $89.0 \pm 4.3 \mathrm{~min}^{-1}(p<0.05)$. BP did not change significantly. When the participants were breathing ambient air, their $\mathrm{SpO}_{2}$ and $\mathrm{HR}$ were recovering, reaching the initial values by the beginning of the next IHT cycle.

\begin{tabular}{|l|c|c|}
\hline \multicolumn{1}{|c|}{ Orthostatic tilt test parameters } & Before HDBR & After HDBR \\
\hline Number of completed OTT/total number of OTT & $13 / 16$ & $7 / 16^{*}$ \\
\hline Average test duration, min & $18.6 \pm 0.8$ & $13.8 \pm 1.6^{*}$ \\
\hline Average time to presyncope, min & $12.7 \pm 1.6$ & $9.0 \pm 1.4^{*}$ \\
\hline
\end{tabular}

Note: OTT - orthostatic tilt test; * $-p<0.05$ 


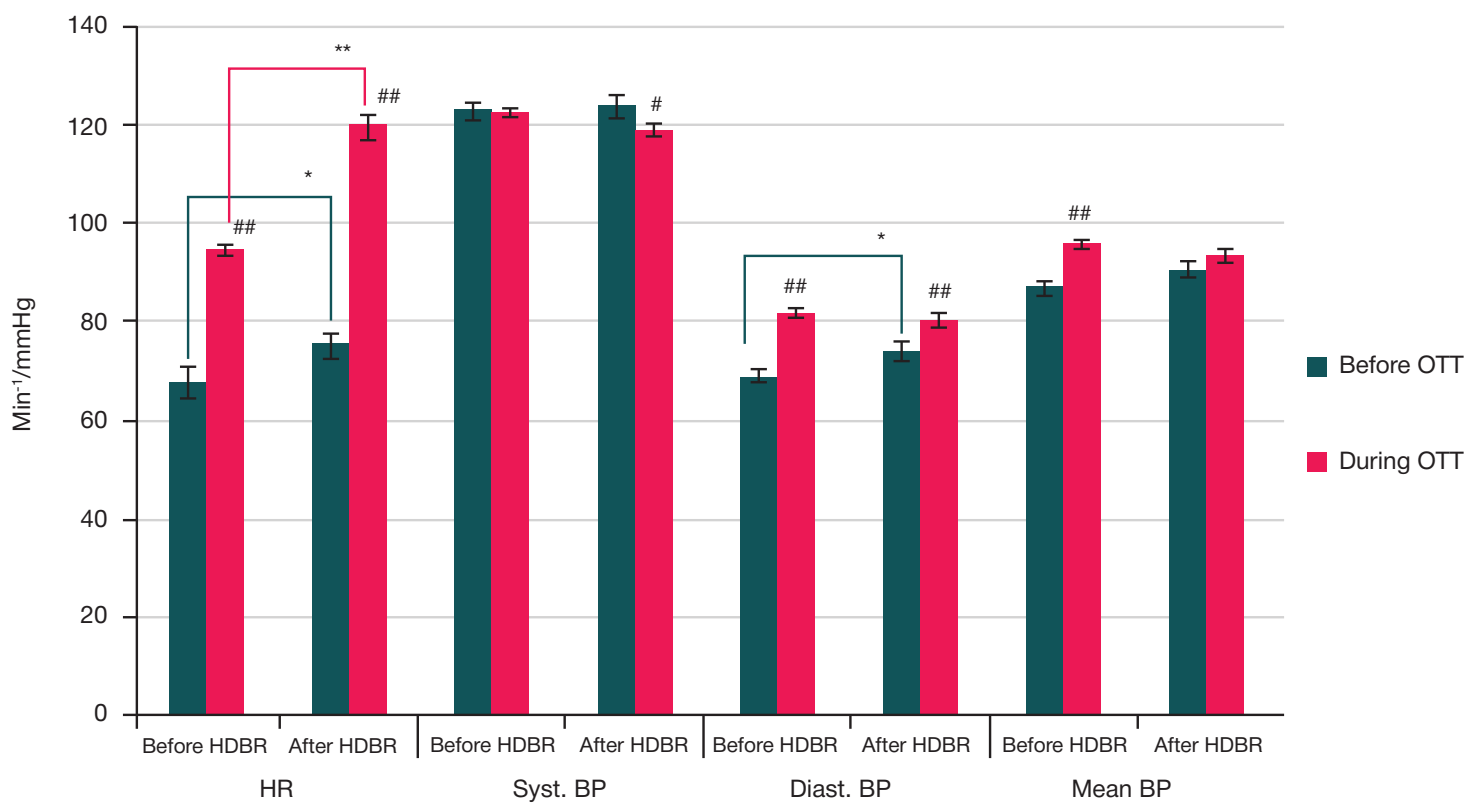

Fig. 1. Effects of 3-day HDBR on cardiovascular responses to the orthostatic test. ${ }^{*}(p<0.05)$ and $\#(p<0.01)$ designate differences between the data obtained during OTT and the data obtained from supine subjects before OTT; ${ }^{*}(p<0.05)$ and ${ }^{* *}(p<0.01)$ designate differences before and after HDBR

\section{Effects of 3-day HDBR on orthostatic tolerance}

The Table below shows the results of OTT before and after 3 days of HDBR. After HDBR, the number of successfully completed OTTs dropped from 13 to 7 , whereas the number of OTTs terminated due to the symptoms of presyncope increased threefold, from 3 to 9 ( $p<0.05)$. For the group, the average time of OTT after HDBR significantly decreased by 4.8 min $(p<0.05)$ in comparison with the control.

In addition to the increased number of presyncopies, time from tilting the subjects upward to the onset of presyncopal symptoms also tended to decrease by $3.7 \mathrm{~min}$.

Following 3 days of HDBR, the mean HR during OTT exceeded the control values by $26.8 \%$ and was $119.8 \pm 2.6 \mathrm{~min}^{-1}$ vs. $94.6 \pm 0.9 \mathrm{~min}^{-1}$ before HDBR $(p<0.01$; Fig. 1$)$. Moreover, the post-HBDR HR was significantly higher in the experimental group than in the controls throughout the test (Fig. 2). The significant increase in HR was accompanied by a slight (about $5 \%$ ) yet reliable mean systolic BP fall from $123.8 \pm 2.2$ to 118.8 $\pm 1.3 \mathrm{mmHg}$ and an elevation of diastolic BP, which was less pronounced in the experimental group: $8.9 \%$ (from $73.9 \pm 1.6$ to $80.5 \pm 1.2 \mathrm{mmHg}$ ) vs. $18.5 \%$ in the control group (from 69.2 \pm 1.4 to $82 \pm 0.6 \mathrm{mmHg}$ ). There was no reliable increase in the mean BP (see Fig. 1). Of note, the absolute values of $\mathrm{HR}$ and diastolic BP measured in the supine position before the initial OTT were $11 \%$ and $6.8 \%$ lower, respectively, than the absolute values of $\mathrm{HR}$ and diastolic BP measured in the antiorthostatic position before the post-HDBR tilt test $(p<0.05)$.

\section{Effects of 11-day IHT on orthostatic tolerance}

In the first part of the experiment, OTTs (before and after HDBR) were carried out on 6 participants. Later, one of them decided to drop out. Consequently, the effects of $I H T$ on orthostatic tolerance before and after HDBR were investigated in a group of 5 individuals, and the data on the dropout was not included in the analysis.

Before HDBR, the tilt test was completed by 4 (80\%) of 5 participants; after IHT, 5 of them (100\%) were able to pass the test. Initially, of 5 OTTs performed after HDBR, 3 (60\%) were

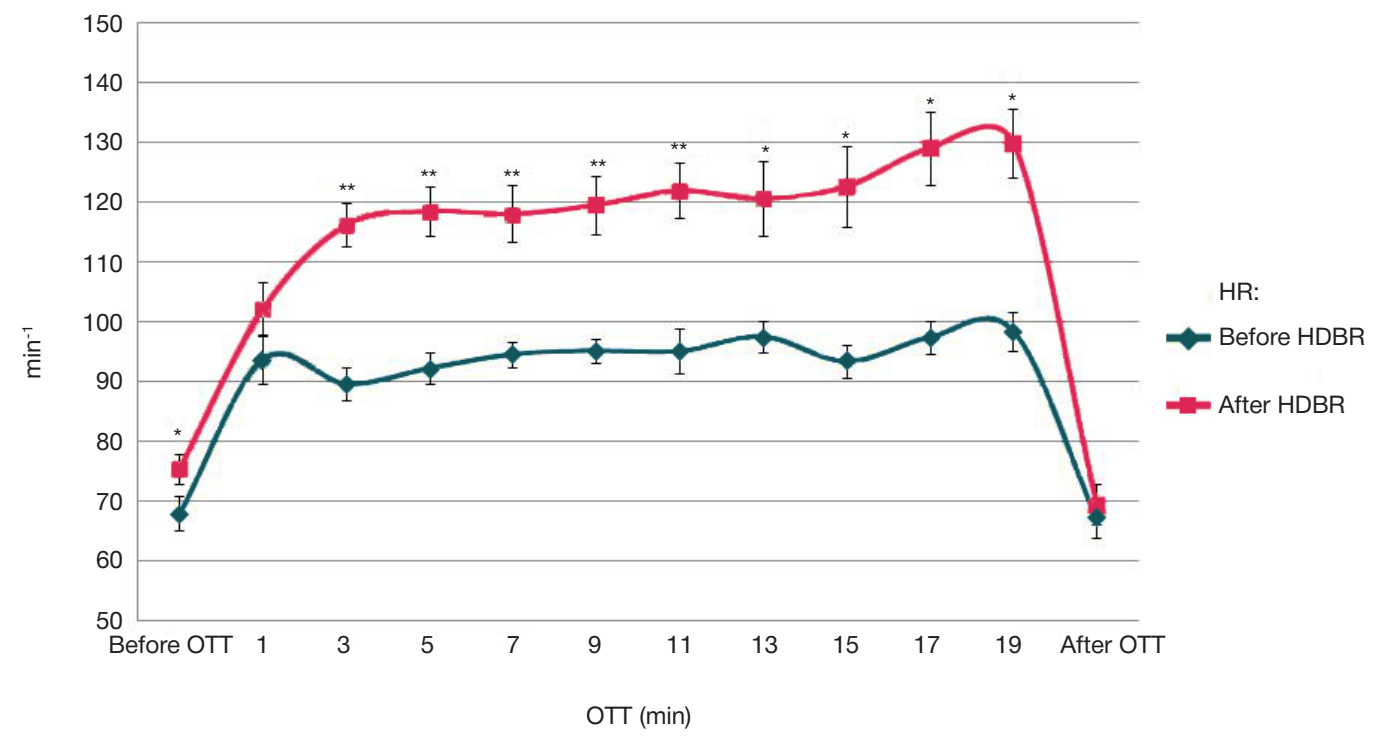

Fig. 2. HR dynamics during the orthostatic test before and after 3 days of HDBR. ${ }^{*}(p<0.05)$ and ${ }^{* *}(p<0.01)$ designate differences before and after HDBR 


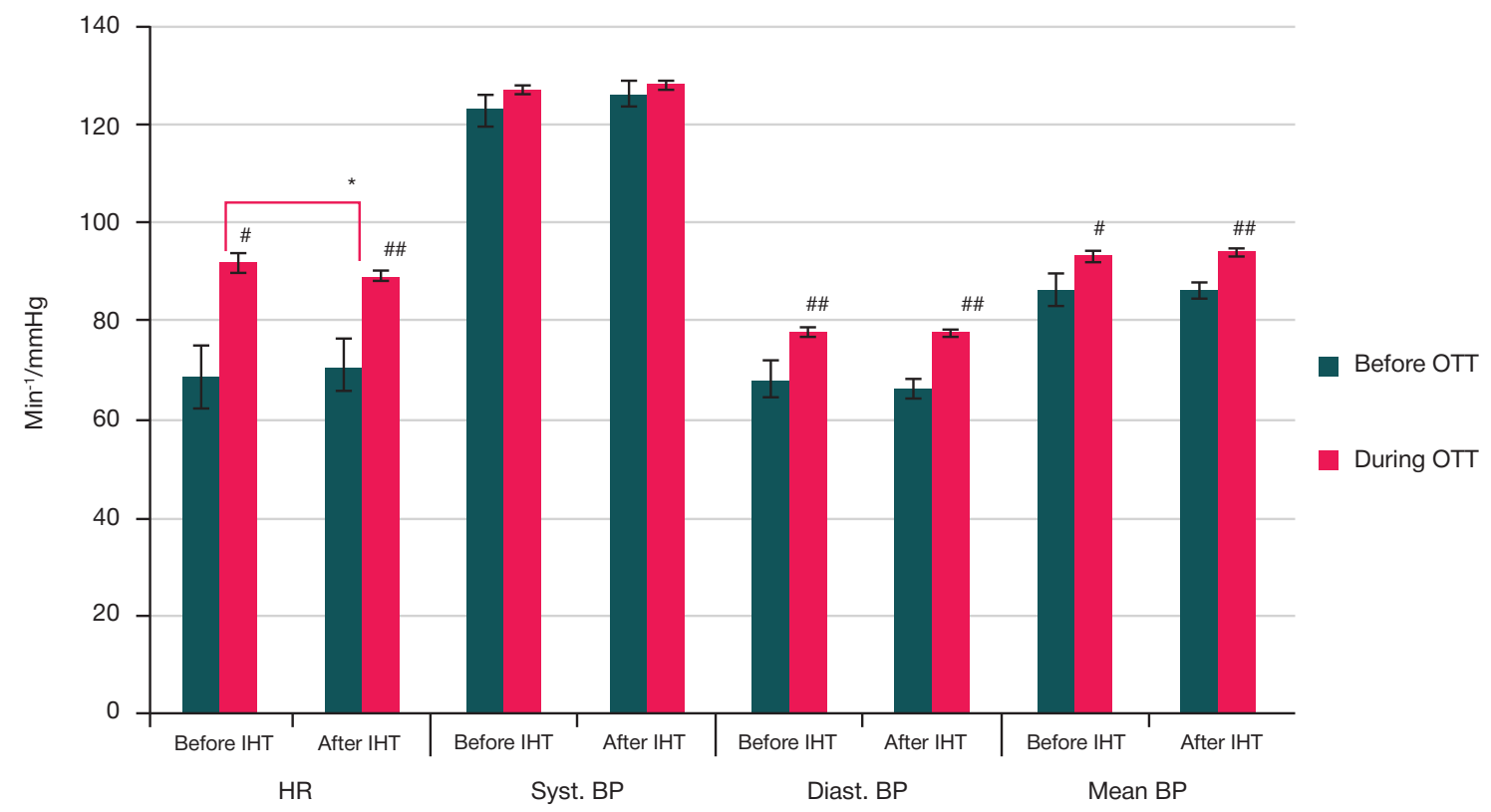

Fig. 3. Effects of 11-day IHT on cardiovascular responses to the orthostatic test before HDBR. \# $(p<0.05)$ and \#\# $(p<0.01)$ designate differences between the data obtained during OTT and the data obtained from supine subjects before OTT; ${ }^{*}(p<0.05)$ marks differences before and after IHT

terminated because the participants became presyncopal. However, IHT presyncopal symptoms were observed in only one (20\%) of 5 participants. The mean OTT duration tended to increase from $13.4 \pm 3.5 \mathrm{~min}$ to $18.6 \pm 1.6 \mathrm{~min}$.

The effects of 11-day $1 \mathrm{HT}$ on the cardiovascular system undergoing orthostatic exposure are shown in Fig. 3. IHT before HDBR resulted in a less pronounced (3\%) increase in HR $(p<0.05)$ in comparison with no IHT. Interestingly, the increase in $\mathrm{HR}$ during $\mathrm{OTT}$ after HDBR was much less pronounced $(16.1 \% ; p<0.05)$ in the participants who had completed the IHT program than in the control group (Fig. 4). Other IHT effects included a stable systolic BP and a higher mean BP (7.2\%; $p<0.05)$.

\section{Effects of 21-day IHT on orthostatic tolerance}

Of 10 participants included in the second part of the experiment, $8(80 \%)$ individuals were able to successfully complete pre-IHT
OTT before HDBR, whereas after IHT 9 (90\%) subjects were able to pass the test. In 3 cases ( 2 before IHT and 1 after IHT), OTT was terminated because the participants developed the symptoms of presyncope. A slight (4.9\%) increase in mean orthostatic tolerance $(18.2 \pm 1.2$ vs. $19.1 \pm 0.9 \mathrm{~min})$ was observed in the participants who had undergone the IHT program, as compared with the control group.

Prior to $\mathrm{IHT}, 4(40 \%)$ of 10 participants were able to complete OTT after HDBR; their number increased to $6(60 \%)$ after IHT. In 6 cases before $\mathrm{IHT}$ and 4 cases after $\mathrm{IHT}$, OTT was terminated because the participants were showing the signs of presyncope. There was a tendency to better tilt test tolerance in the group that had undergone the $\mathrm{IHT}$ program: the test duration increased from $13.4 \pm 2.1$ to $14.7 \pm 2.2 \mathrm{~min}$, i.e. by $9.7 \%$, in this group as compared to the control.

The effects of IHT on hemodynamics observed during OTT before HDBR are provided in Fig. 5. In comparison with the control group, HR, diastolic BP and mean BP increased

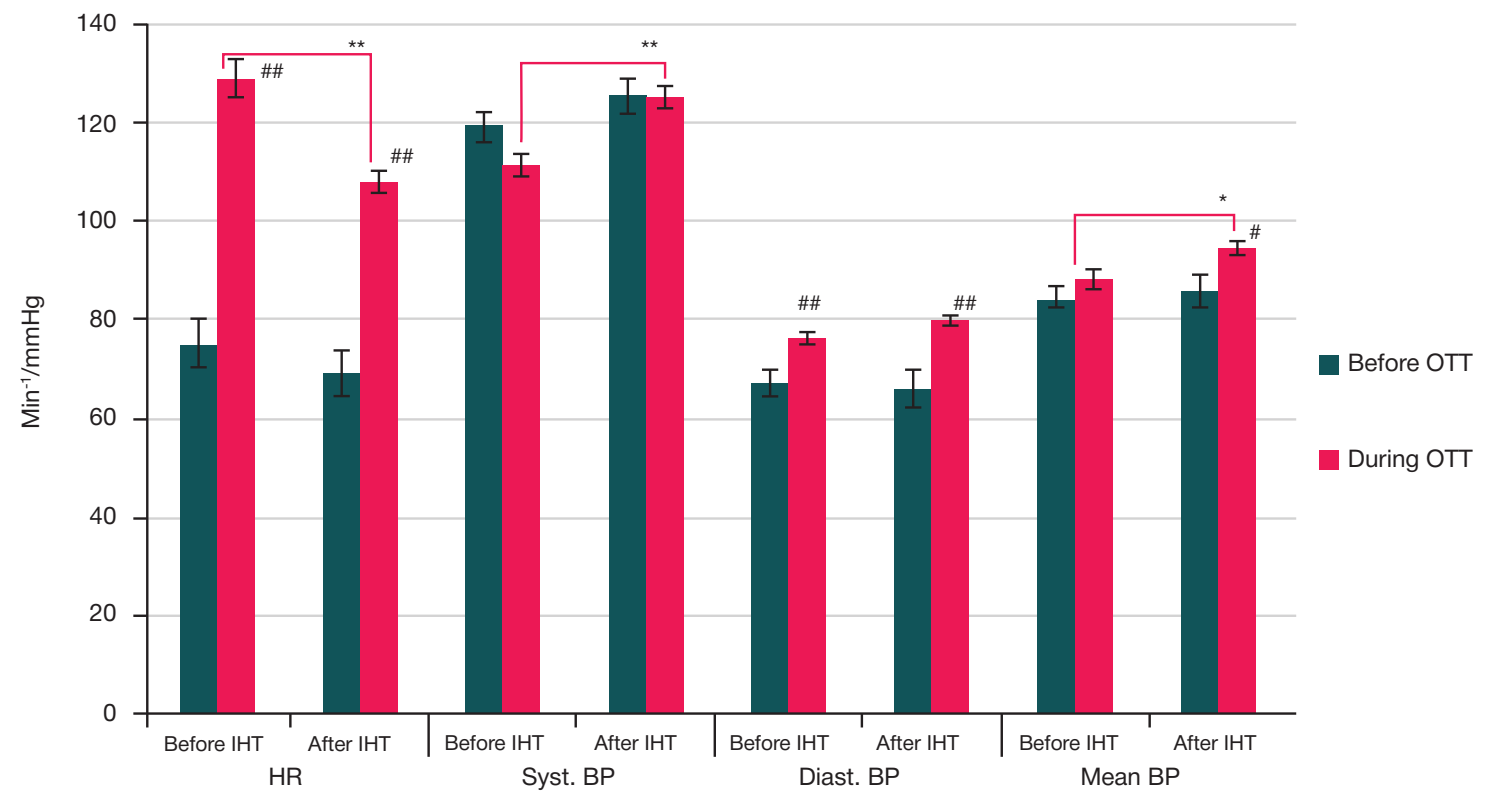

Fig. 4. Effects of 11-day IHT on cardiovascular responses to the orthostatic test after HDBR. \# $(p<0.05)$ and \#\# $(p<0.01)$ designate differences between the data obtained during OTT and the data obtained from supine subjects before OTT; ${ }^{*}(p<0.05)$ and ${ }^{* *}(p<0.01)$ designate differences before and after IHT 


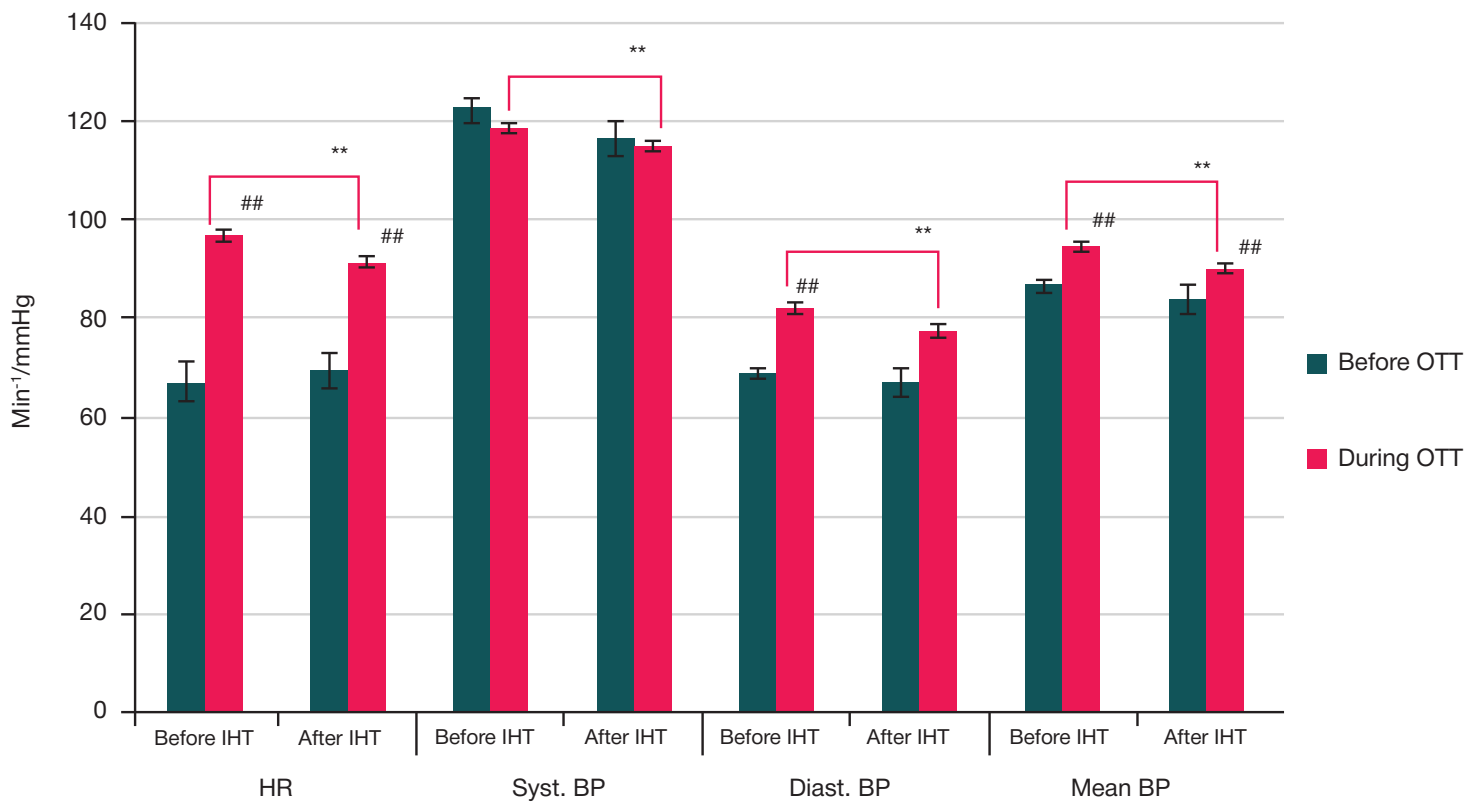

Fig. 5. Effects of 21-day IHT on cardiovascular responses to the orthostatic test before HDBR. ${ }^{\#}(p<0.05)$ and ${ }^{\#}(p<0.01)$ designate differences between the data obtained during OTT and before OTT; * $(p<0.01)$ marks differences before and after HDBR

less dramatically during OTT (by $5.4 \%, 6.3 \%$ and $5.1 \%$, respectively; $p<0.01$ ) in the participants who had completed the IHT program. Systolic BP did not change significantly during OTT but was 3.3\% lower than before $\mathrm{HTT}(p<0.01)$.

During the post-HDBR tilt test (Fig. 6) performed after IHT, an increase in $\mathrm{HR}$ was less pronounced $(4.6 \%)$ and $\mathrm{BP}$ values were lower $(5.8 \%)(p<0.05)$. Before OTT, HR, diastolic BP and mean BP were $14.5 \%, 5.1 \%$ and $4.3 \%$ lower in the participants who had completed the $\mathrm{IHT}$ program than in the control group $(p<0.05)$.

\section{DISCUSSION}

The study demonstrates that 3 days of HDBR reduces OT in human subjects. After HDBR, significantly fewer participants could complete the test due to the symptoms of presyncope and the trending early onset of such symptoms in the vertical position. After 3 days of HDBR, orthostatic intolerance was

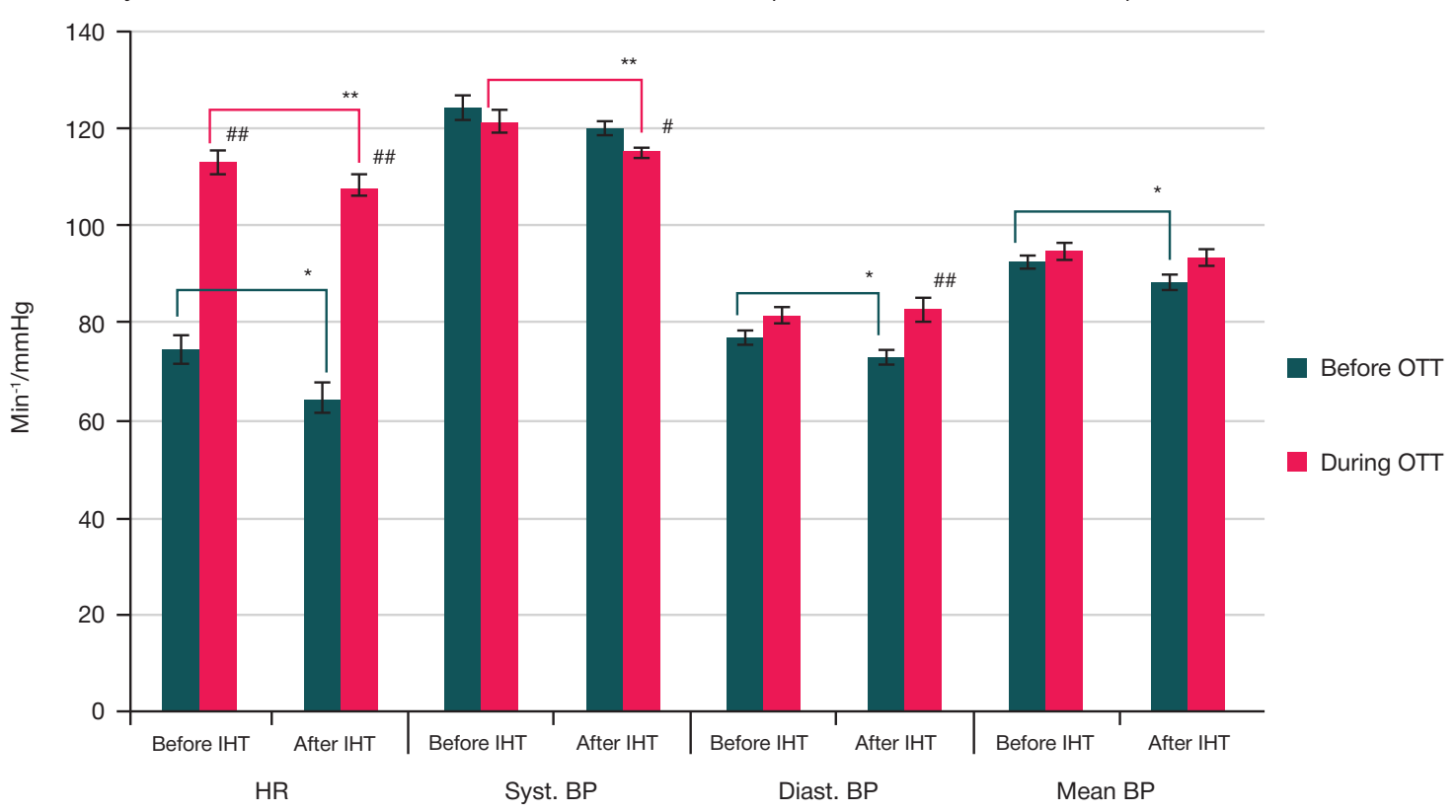

Fig. 6. Effects of 21-day IHT on cardiovascular responses to orthostatic test after HDBR. ${ }^{*}(p<0.05)$ and ${ }^{\# \#}(p<0.01)$ designate differences between the data obtained during OTT and before OTT; * $(p<0.05)$ and ${ }^{* *}(p<0.01)$ designate differences before and after IHT observed in 9 (56.3\%) of the total 16 participants. Our findings support the data generated by other studies. It is reported that after 4 days of HDBR, as many as $5(63 \%)$ of 8 subjects were unable to finish the orthostatic test $[18,19]$. There is evidence that orthostatic intolerance can develop after shorter exposures to HDBR. For example, 6 (75\%) of 8 participants became presyncopal during OTT after only $4 \mathrm{~h}$ of HDBR [20].

Differences in the estimated frequency of orthostatic intolerance after HDBR might largely be due to the employment of different methods for OTT, different tilt table angles (60 to $80^{\circ}$ ), OTT duration (10-20 to $60 \mathrm{~min}$ ), application of negative pressure to the lower body after OTT, nonuniform criteria for assessing OT (based on test duration or the onset of presyncope), individual physiological response to OTT [21, 22].

The key role in maintaining systemic BP and cerebral circulation during orthostatic exposure is attributed to the cardiovascular system [23]. In our study, the hemodynamic response to orthostatic exposure was characterized by 
pronounced tachycardia and low systolic BP after HDBR. These findings are consistent with the results of space flight studies [24] and studies of antiorthostatic hypokinesia [25].

Pronounced tachycardia observed during OTT after HDBR should be considered a symptom of cardiovascular deconditioning caused by hypokinesia. It is known that $-6^{\circ}$ HDBR leads to blood/fluid redistribution toward the skull and increases the blood volume in the thoracic compartment [26]. Increased venous return to the right atrium triggers secretion of the atrial natriuretic peptide [27]. This results in reduced water reabsorption, diuresis, increased natriuresis and, eventually, decreased plasma volume. After 2 days of HDBR, the central blood volume drops by approximately $11 \%$ [28], and the plasma volume decreases by $6.1 \%$ [29]. It normally takes 2 to 4 days for the cardiovascular and related systems to adapt to HDBR; the adaptive state is characterized by slower $\mathrm{HR}$ and slightly lower BP [30]. Higher HR and diastolic BP in the antiorthostatic position before OTT after 3 days of HDBR vs. HR and $\mathrm{BP}$ in the horizontal position before the initial OTT observed in our study suggest that the body was still adjusting its water-electrolyte balance to the new environment.

In the setting of moderate hypovolemia that develops after 1 week of a spaceflight/ HDBR, the left ventricular enddiastolic volume, the stroke volume and the cardiac size diminish [31]. Apart from the small stroke volume, increased venous distension in the lower limbs, which often develops during HDBR and spaceflights, is also a precipitating factor for orthostatic disorders: orthostatic exposure increases blood flow to leg veins and makes it difficult for the body to maintain adequate cardiac output in the vertical position [32].

The baroreflex mechanism relying on the receptors of carotid sinuses and the aortic arch is the crucial component of neural circulatory control. The baroreflex regulation of BP is largely implemented through the modulation of $\mathrm{HR}$ and the vasomotor activity of the sympathetic nervous system (SNS) [33]. A positive correlation has been established between the level of vasomotor SNS activity and total vascular resistance in young men [34]; unlike changes in the central hemodynamics and HR reported by another study [35], vascular resistance turned out to be critical in maintaining BP in astronauts during OTT after short-duration (9-14 days) space missions. These results are well correlated with the data generated by another study [36]. According to the publication, preexposure prophylaxis with midodrine, which is known to enhance vasoconstriction, prevented syncope due to orthostatic exposure in all of 5 study participants following their return to Earth. It is reported that the baroreflex control of vasomotor SNS activity is weakened during HDBR and the subsequent OTT [21]. Today, it is believed that decreased baroreflex sensitivity is one of the principal causes of poor orthostatic tolerance in the setting of hypokinesia and microgravity $[21,25,30]$.

\section{References}

1. Gazenko OG, Grigoriev Al, Egorov AD. Reakcii organizma cheloveka v uslovijah kosmicheskogo poleta. V knige: Gazenko OG, Kasjan II, redaktory. Fiziologicheskie problemy nevesomosti. M., 1990; s. 15-48. Russian.

2. Charles JB, Bungo MW, Fortner GW. Cardiopulmonary function. In: Nicogossian AE, Huntoon CL, Pool S, editors. Space Physiology and Medicine. 3rd ed. Lea \& Febiger. A Waverly Company; 1994. Section III, Chart.14, p. 286-304.

3. Meck JV, Reyes CJ, Perez SA, Goldberger AL, Ziegler MG. Marked exacerbation of orthostatic intolerance after long- vs.
Performing $\mathrm{IHT}$ reduces the risk of orthostatic disorders. This can be inferred from the less pronounced changes in cardiovascular parameters during orthostatic exposure and fewer cases of presyncopal symptoms before and after HDBR. The increase in HR during OTT before HDBR was smaller in the group that had completed the 11-day IHT program than in the control group. The extended 21-day IHT program led to less pronounced changes in $\mathrm{HR}$, systolic, diastolic and mean BP. The increase in HR during OTT after HDBR was significantly lower in the participants who had completed the 11-day IHT program; at the same time, systolic BP was stable. Both HR and systolic BP were lower in the group subjected to the extended $\mathrm{IHT}$ regimen. $\mathrm{HR}$, systolic and diastolic BP values after IHT preceding the test were lower than before IHT, suggesting faster adaptation to HDBR.

According to the literature, the beneficial effects of $\mathrm{HT}$ observed in our study might be connected to certain changes in the functional state of the autonomic nervous system and the cardiovascular system occurring during adaptation to repeated hypoxic exposure [11]. The mechanisms of immediate adaptation to hypoxia rely on the sympathetic activation of the compensatory cardiorespiratory response, which aims to reduce arterial hypoxemia and improve oxygen transport to tissues [16]. Repeated exposure to moderate hypoxia and reoxygenation create a structural and functional basis for the mechanisms that underlie long-term adaptation to hypoxia and improve oxygen uptake by mitochondria [37]. The long-term effects of IHT include enhanced performance of the parasympathetic components of circulatory control and higher efficacy of baro-and chemoreceptor-based regulation of heart rhythm and vascular tone [38]. Regional blood flow is redistributed toward the brain and the heart. IHT has been shown to exert a beneficial effect on vascularization and myocardial contractility [39]. This leads us to hypothesize that IHT might have had a cardioprotective effect on our subjects by increasing myocardial capacity and negating the main detrimental effects of orthostasis manifested as a dramatic BP decline.

\section{CONCLUSION}

Pronounced tachycardia during OTT after HDBR should be considered a sign of cardiovascular deconditioning due to limited physical activity during hypokinetic periods. Preexposure to IHT ameliorates cardiovascular strain during orthostatic tests before and after 3 days of HDBR. IHT reduces the risk of orthostatic syncope. The mechanisms underlying IHT effects on the functional state and ratio of cardiac to vascular components maintaining circulatory homeostasis during orthostatic exposure require further elucidation. short-duration spaceflight in veteran astronauts. Psychosom Med. 2001; 63: 865-73.

4. Lee SMC, Feiveson AH, Stein S, Stenger MB, Platts $\mathrm{SH}$. Orthostatic intolerance after ISS and Space Shuttle missions. Aerosp Med Hum Perform. 2015; 86 (12 Suppl.): A54-67.

5. Kozlovskaya IB, Yarmanova EN, Egorov AD, Stepantsov VI, Fomina EV, Tomilovskaya ES i dr. Razvitie rossijskoj sistemy profilaktiki neblagoprijatnyh viljanij nevesomosti v dlitel'nyh poletah na MKS. V knige: Grigor'ev A. I., redaktor. Mezhdunarodnaja kosmicheskaja stancija. Rossijskij segment. M.: Uchrezhdenie 
RAN Gosudarstvennyj nauchnyj centr RF — Institut medikobiologicheskih problem, 2011; 1: 63-98. Russian.

6. Kotovskaya AR, Fomina GA. Serdechno-sosudistaya sistema cheloveka. In: Grigoriev Al, Ushakov IB, redaktory. Kosmicheskaja medicina i biologija: sbornik nauchnyh statej. Voronezh: IPC «Nauchnaja kniga», 2013; s. 306-20. Russian.

7. Baranov VM, Katuntsev VP, Baranov MV, Shpakov AV, Tarasenkov GG Vyzovy kosmicheskoj medicine pri osvoenii chelovekom Luny: riski, adaptacija, zdorov'e, rabotosposobnost'. Ul'janov. medbiol. zhurnal. 2018; 3: 109-23. Russian.

8. Kotov AN, Zakharov SYu, Rudenko EA, Baranov VM. Vlijanie mnogosutochnoj antiortostaticheskoj i ortostaticheskoj gipokinezii na ortoustojchivost' cheloveka. Medicina jekstremal'nyh situacij. 2016; 1: 25-9. Russian.

9. Orlov OI, Koloteva MI, Shipov AA. Issledovaniya na ustanovkakh medlennogo vrashcheniya. In: Grigorev AI, Ushakov IB, redaktory. Kosmicheskaja medicina i biologija: sbornik nauchnyh statej. Voronezh: IPC «Nauchnaja kniga», 2013; s. 562-9. Russian.

10. Solopov I. N. Podgotovka cheloveka k dlitel'nomu kosmicheskomu poletu v uslovijah modelirovanija jekstremal'nyh situacij. Medicina jekstremal'nyh situacij. 2016; 1: 71-5. Russian.

11. Meerson F. Z. Obshhij mehanizm adaptacii i profilaktiki. M.: Medicina, 1973; 360 s. Russian.

12. Ushakov IB, Bukhtiyarov IV, Shishov AA, Olenev NI. Gipobaricheskaja interval'naja gipoksija kak metod dlja povyshenija ustojchivost k vozdejstviju professional'no vrednyh faktorov. Vestnik Ros. akademii med. nauk. 2010; 12: 3-7. Russian.

13. Serebrovskaya T, Xi L. Intermittent hypoxic training as nonpharmacological therapy for cardiovascular diseases: Practical analysis on methods and equipment. Exp Biol Med. 2016; 241 (15): 1708-23

14. Lesova EM, Filippova EB, Golubev VN, Dergachev VB. Vlijanie interval'nyh gipoksicheskih trenirovok na pokazateli gemodinamiki pri ortostaticheskoj nagruzke. Vestn. Ross. voenn.-med. akad. 2015; 3 (51): 109-13. Russian.

15. Donina ZhA. Rol' gipoksicheskogo vozdejstvija $\vee$ snizhenii ortostaticheskih rasstrojstv posle prebyvanija $v$ uslovijah modelirovannoj nevesomosti. Medicina jekstremal'nyh situacij. 2016; 1: 63-70. Russian.

16. Donina ZhA, Baranova EV, Aleksandrova NP, Katuntcev VP, Baranov VM. Normobaricheskaja periodicheskaja gipoksija povyshaet ortostaticheskuju rezistentnost' krys posle modelirovannoj nevesomosti. Ros. fiziol. zhurn. im. IM. Sechenova. 2018; 104 (11): 1301-12. Russian.

17. Genin AM, Pestov ID. Mikrogravitacija: mehanizmy i modeli. V knige: Antipov W, Grigorev Al, Lich Hantun K, redaktory. Chelovek v kosmicheskom polete. M.: Nauka, 1997; s. 460-80. Russian.

18. Pavy-Le Traon A, Sigaudo D, Vasseur P, Fortrat JO, Güell A, Hughson RL, et al. Orthostatic tests after a 4-day confinement or simulated weightlessness. Clinical Physiology. 1997; 17: 41-55.

19. Arbeille P, Sigaudo D, Pavy Le Traon A, Herault S, Porcher M, Gharib C. Femoral to cerebral arterial blood flow redistribution and femoral vein distension during orthostatic tests after 4 days in the head-down tilt position or confinement. European Journal of Applied Physiology and Occupational Physiology. 1998; 78: 208-18.

20. Butler GC, Xing H, Northey DR, Hughson RL. Reduced orthostatic tolerance following $4 \mathrm{~h}$ head-down tilt. Eur J Appl Physiol. 1991; 62: 26-30.

21. Barbic F, Heusser K, Minonzio M, Shiffer D, Cairo B, Tank J et al. Effects of prolonged head-down bed rest on cardiac and vascular baroreceptor modulation and orthostatic tolerance in healthy individuals. Frontiers in Physiology. 2019; 10. Article 1061.

22. Pavy-Le Traon A, Heer M, Narici MV, Rittweger J, Vernikos J. From space to Earth: advances in human physiology from 20

\section{Литература}

1. Газенко О. Г., Григорьев А. И., Егоров А. Д. Реакции организма человека в условиях космического полета. В книге: Газенко О. Г., Касьян И. И., редакторы. Физиологические проблемь невесомости. М., 1990; с. 15-48. years of bed rest studies (1986-2006). Eur Journal of Applied Physiology. 2007; 101: 143-94.

23. Osadchy LI. Polozhenie tela i reguljacija krovoobrashhenija. L.: Nauka, 1982; 145 c. Russian.

24. Norsk P, Asmar A, Damgaard M, Christensen NJ. Fluid shifts, vasodilatation and ambulatory blood pressure reduction during long duration spaceflight. J Physiol. 2015; 593 (3): 573-84.

25. Convertino VA, Doerr DF, Eckberg DL, Fritsch JM, VernikosDanellis J. Head-down bed rest impairs vagal baroreflex responses and provokes orthostatic hypotension. J Appl Physiol. 1990; 68 (4): 1458-64

26. Katkov VE, Chestukhin W, Nikolaenko EM, Rumyantsev W, Gvozdev SV. Central'noe krovoobrashhenie zdorovogo cheloveka vo vremja 7-sutochnoj antiortostaticheskoj gipokinezi i dekompressii razlichnyh oblastej tela. Kosmicheskaja biologija aviakosmicheskaja medicina. 1984; 1: 80-90. Russian.

27. Maillet A, Pavy-Le Traon A, Allevard AM, Sigaudo D, Hughson RL, Gharib C, et al. Hormone changes induced by 37.5-h head-down tilt (-6). J Appl Physiol. 1994; 68: 497-503.

28. Lobachik VI, Abrosimov SV, Zhidkov VV, Endeka DK. Hemodynamic effects of microgravity and their groundbased simulations. 8th IAA Man in space symposium. Acta Astronaut. 1991; 23: 35-40.

29. Johansen LB, Gharib C, Allevard AM, Sigaudo D, Christensen NJ, Drummer C. et al. Haematocrit, plasma volume and noradrenaline in humans during simulated weightlessness for 42 days. Clin Physiol. 1997; 17: 203-10.

30. Amirova L, Navasiolava N, Rukavishvikov I, Gauquelin-Koch G, Gharib C, Kozlovskaya I, et al. Cardiovascular system under simulated weightlessness: head-down bed rest vs. dry immersion. Frontiers in Physiology. 2020: 11. Article 3952020

31. Arbeille P, Fomina G, Roumy J, Alferova I, Tobal N, Herault S. Adaptation of the left heart, cerebral and femoral arteries, and jugular and femoral veins during short-and long-term headdown tilt and spaceflights. Europ J Appl Physiol. 2001; 86: 157-68.

32. Kotovskaya AR, Fomina GA, Salnikov VA. Issledovanija sostojanija ven goleni kosmonavtov v povtornyh 6-mesjachnyh kosmicheskih poletah na RS MKS. Aviakosmich. i jekologich. med. 2019; 53 (1) 44-8. Russian.

33. Taylor CE, Witter T, Sayed K, Hissen SL, Johnson AW, Macefield VG. Relationship between spontaneous sympathetic baroreflex sensitivity and cardiac baroreflex sensitivity in healthy young individuals. Physiol Rep. 2015; 3 (11): 1-10.

34. Hart EC, Joyner MJ, Wallin BG, Karlsson T, Curry TB, Charkoudian N. Baroreflex control of muscle sympathetic nerve activity: a nonpharmacological measure of baroreflex sensitivity. Am J Physiol Heart Circ Physiol. 2009; 298: H816-22.

35. Buckey JC, Lane LD, Levine BD, Watenpaugh DE, Wright SJ, Moore WE, et al. Orthostatic intolerance after spaceflight. J Appl Physiol. 1996; 81 (1): 7-18.

36. Platts SH, Ziegler MG, Waters WW, Meck JV. Hemodynamic effects of midodrine after space flight in astronauts without orthostatic hypotension. Aviat Space Environ Med. 2006; 77: 429-33.

37. Lukyanova LD. Signal'nye mehanizmy gipoksii. M.: RAN, 2019 215 c. Russian.

38. Bobyleva OV, Glazachev OS. Dinamika pokazatelej vegetativno reaktivnosti i ustojchivosti k ostroj dozirovannoj gipoksii v kurse interval'noj gipoksicheskoj trenirovki. Fiziologija cheloveka. 2007; 33 (2): 81-9. Russian

39. Balykin MV, Sagidova SA, Zhirkov AS, Ayzyatulova ED, Pavlov DA, Antipov IV. Vlijanie preryvisnoj gipobaricheskoj gipoksii na jekspressiju HIF-1 $\alpha$ i morfofunkcional'nye izmenenija v miokarde. Ul'janov. med-biol. zhurnal. 2017; (2): 125-34. Russian. 
3. Meck JV, Reyes CJ, Perez SA, Goldberger AL, Ziegler MG. Marked exacerbation of orthostatic intolerance after long- vs. short-duration spaceflight in veteran astronauts. Psychosom Med. 2001; 63: 865-73.

4. Lee SMC, Feiveson AH, Stein S, Stenger MB, Platts SH. Orthostatic intolerance after ISS and Space Shuttle missions. Aerosp Med Hum Perform. 2015; 86 (12 Suppl.): A54-67.

5. Козловская И. Б., Ярманова Е. Н., Егоров А. Д., Степанцов В. И., Фомина Е. В., Томиловская Е. С. и др. Развитие российской системы профилактики неблагоприятных влияний невесомости в длительных полетах на МКС. В книге: Григорьев А. И., редактор. Международная космическая станция. Российский сегмент. М.: Учреждение РАН Государственный научный центр РФ - Институт медикобиологических проблем, 2011; 1: 63-98.

6. Котовская А. Р., Фомина Г. А. Сердечно-сосудистая система человека. В книге: Григорьев А. И., Ушаков И. Б., редакторы. Космическая медицина и биология: сборник научных статей. Воронеж: ИПЦ «Научная Книга», 2013; с. 306-20.

7. Баранов В. М., Катунцев В. П., Баранов М. В., Шпаков А. В., Тарасенков Г. Г. Вызовы космической медицине при освоении человеком Луны: риски, адаптация, здоровье, работоспособность. Ульянов. мед-биол. журнал. 2018; 3: $109-23$.

8. Котов А. Н., Захаров С. Ю., Руденко Е. А., Баранов В. М. Влияние многосуточной антиортостатической и ортостатической гипокинезии на ортоустойчивость человека. Медицина экстремальных ситуаций. 2016; 1: 25-9.

9. Орлов О. И., Колотева М. И., Шипов А. А. Исследования на установках медленного вращения. В книге: Григорьев А. И., Ушаков И. Б., редакторы. Космическая медицина и биология: сборник научных статей. Воронеж: ИПЦ "Научная книга", 2013; с. 562-9.

10. Солопов И. Н. Подготовка человека к длительному космическому полету в условиях моделирования экстремальных ситуаций. Медицина экстремальных ситуаций. 2016; 1: 71-5.

11. Меерсон Ф. З. Общий механизм адаптации и профилактики. М.: Медицина, 1973; 360 с.

12. Ушаков И. Б., Бухтияров И. В., Шишов А. А., Оленев Н. И. Гипобарическая интервальная гипоксия как метод для повышения устойчивости к воздействию профессионально вредных факторов. Вестник Рос. академии мед. наук. 2010; 12: $3-7$.

13. Serebrovskaya $T, X i L$. Intermittent hypoxic training as nonpharmacological therapy for cardiovascular diseases: Practical analysis on methods and equipment. Exp Biol Med. 2016; 241 (15): 1708-23.

14. Лесова Е. М., Филиппова Е.Б., Голубев В. Н., Дергачёв В. Б. Влияние интервальных гипоксических тренировок на показатели гемодинамики при ортостатической нагрузке. Вестн. Росс. военн.-мед. акад. 2015; 3 (51): 109-13.

15. Донина Ж. А. Роль гипоксического воздействия в снижении ортостатических расстройств после пребывания в условиях моделированной невесомости. Медицина экстремальных ситуаций. 2016; 1: 63-70.

16. Донина Ж. А., Баранова Е. В., Александрова Н. П., Катунцев В. П., Баранов В. М. Нормобарическая периодическая гипоксия повышает ортостатическую резистентность крыс после моделированной невесомости. Рос. физиол. журн. им. И. М. Сеченова. 2018; 104 (11): 1301-12.

17. Генин А. М., Пестов И. Д. Микрогравитация: механизмы и модели. В книге: Антипов В. В., Григорьев А. И., Лич Хантун К., редакторы. Человек в космическом полете. М.: Наука, 1997; c. $460-80$

18. Pavy-Le Traon A, Sigaudo D, Vasseur P, Fortrat JO, Güell A, Hughson RL, et al. Orthostatic tests after a 4-day confinement or simulated weightlessness. Clinical Physiology. 1997; 17: 41-55.

19. Arbeille P, Sigaudo D, Pavy Le Traon A, Herault S, Porcher M, Gharib C. Femoral to cerebral arterial blood flow redistribution and femoral vein distension during orthostatic tests after 4 days in the head-down tilt position or confinement. European Journal of Applied Physiology and Occupational Physiology. 1998; 78: 208-18.

20. Butler GC, Xing H, Northey DR, Hughson RL. Reduced orthostatic tolerance following $4 \mathrm{~h}$ head-down tilt. Eur J Appl Physiol. 1991 62: 26-30.

21. Barbic F, Heusser K, Minonzio M, Shiffer D, Cairo B, Tank J et al. Effects of prolonged head-down bed rest on cardiac and vascular baroreceptor modulation and orthostatic tolerance in healthy individuals. Frontiers in Physiology. 2019; 10. Article 1061.

22. Pavy-Le Traon A, Heer M, Narici MV, Rittweger J, Vernikos J. From space to Earth: advances in human physiology from 20 years of bed rest studies (1986-2006). Eur Journal of Applied Physiology. 2007; 101: 143-94.

23. Осадчий Л. И. Положение тела и регуляция кровообращения. Л.: Наука, 1982; 145 с.

24. Norsk P, Asmar A, Damgaard M, Christensen NJ. Fluid shifts, vasodilatation and ambulatory blood pressure reduction during long duration spaceflight. J Physiol. 2015; 593 (3): 573-84.

25. Convertino VA, Doerr DF, Eckberg DL, Fritsch JM, VernikosDanellis J. Head-down bed rest impairs vagal baroreflex responses and provokes orthostatic hypotension. J Appl Physiol. 1990; 68 (4): 1458-64.

26. Катков В. Е., Честухин В. В., Николаенко Э.М., Румянцев В. В., Гвоздев С. В. Центральное кровообращение здорового человека во время 7-суточной антиортостатической гипокинезии и декомпрессии различных областей тела Космическая биология и авиакосмическая медицина. 1984; 1: 80-90.

27. Maillet A, Pavy-Le Traon A, Allevard AM, Sigaudo D, Hughson RL, Gharib C, et al. Hormone changes induced by 37.5-h head-down tilt (-6). J Appl Physiol. 1994; 68: 497-503.

28. Lobachik VI, Abrosimov SV, Zhidkov W, EndekaDK. Hemodynamic effects of microgravity and their groundbased simulations. 8th IAA Man in space symposium. Acta Astronaut. 1991; 23: 35-40.

29. Johansen LB, Gharib C, Allevard AM, Sigaudo D, Christensen NJ, Drummer C. et al. Haematocrit, plasma volume and noradrenaline in humans during simulated weightlessness for 42 days. Clin Physiol. 1997; 17: 203-10

30. Amirova L, Navasiolava N, Rukavishvikov I, Gauquelin-Koch G, Gharib C, Kozlovskaya I, et al. Cardiovascular system under simulated weightlessness: head-down bed rest vs. dry immersion. Frontiers in Physiology. 2020: 11. Article 3952020.

31. Arbeille P, Fomina G, Roumy J, Alferova I, Tobal N, Herault S. Adaptation of the left heart, cerebral and femoral arteries, and jugular and femoral veins during short-and long-term headdown tilt and spaceflights. Europ J Appl Physiol. 2001; 86: 157-68.

32. Котовская А. Р., Фомина Г. А., Сальников В. А. Исследования состояния вен голени космонавтов в повторных 6-месячных космических полетах на РС МКС. Авиакосмич. и экологич. мед. 2019; 53 (1): 44-8.

33. Taylor CE, Witter T, Sayed K, Hissen SL, Johnson AW, Macefield VG. Relationship between spontaneous sympathetic baroreflex sensitivity and cardiac baroreflex sensitivity in healthy young individuals. Physiol Rep. 2015; 3 (11): 1-10.

34. Hart EC, Joyner MJ, Wallin BG, Karlsson T, Curry TB, Charkoudian N. Baroreflex control of muscle sympathetic nerve activity: a nonpharmacological measure of baroreflex sensitivity. Am J Physiol Heart Circ Physiol. 2009; 298: H816-22.

35. Buckey JC, Lane LD, Levine BD, Watenpaugh DE, Wright SJ, Moore WE, et al. Orthostatic intolerance after spaceflight. J App Physiol. 1996; 81 (1): 7-18.

36. Platts SH, Ziegler MG, Waters WW, Meck JV. Hemodynamic effects of midodrine after space flight in astronauts without orthostatic hypotension. Aviat Space Environ Med. 2006; 77 429-33.

37. Лукьянова Л. Д. Сигнальные механизмы гипоксии. М.: РАН, 2019; 215 c.

38. Бобылева О. В., Глазачев О. С. Динамика показателей вегетативной реактивности и устойчивости к острой дозированной гипоксии в курсе интервальной гипоксической тренировки. Физиология человека. 2007; 33 (2): 81-9.

39. Балыкин М. В., Сагидова С. А., Жирков А. С., Айзятулова Е. Д., Павлов Д. А., Антипов И. В. Влияние прерывисной гипобарической гипоксии на экспрессию HIF-1 $\alpha$ и морфофункциональные изменения в миокарде. Ульянов. мед-биол. журнал. 2017; (2): 125-34. 